\title{
The structure of dental procedures under general anaesthesia in children and adolescents with epilepsy
}

\begin{abstract}
Introduction. One of the indications for dental treatment in general anaesthesia of children and adolescents is the patients' refusal to cooperate with the dentist; this concerns especially the so-called special care patients, and among them, those suffering from epilepsy.

Aim. The aim of the study was to evaluate the structure of treatment procedures in conservative dentistry and dental surgery performed under general anaesthesia in children and adolescents with epilepsy.

Material and methods. The analysis covered case histories of 109 patients with epilepsy, aged 3-18 years, who received dental treatment under general anaesthesia. The patients were divided into three age groups, according to the dentition type: patients with deciduous dentition - 3-5 years of age; with mixed dentition - 6-12 years, and with permanent dentition 13-18 years. The analysis concerned the procedures on both deciduous and permanent teeth.

Results. An average number of extractions in a child with full deciduous dentition was 3.9 teeth, while in a child with mixed dentition -2.7 teeth. The greatest number of deciduous teeth extractions concerned first and second molars. Carious cavities in the occlusal surfaces of permanent teeth, due to deep caries, were the most frequently treated lesions.

Conclusions. In patients with epilepsy treated under general anaesthesia, extensive treatment needs, resulting from prophylactic and therapeutic neglect in dental care, were found. Conservative and surgical treatment, combined with prophylactic procedures, performed under general anaesthesia seems one of the necessary elements of a complex dental care in uncooperative children and adolescents.
\end{abstract}

Keywords: epilepsy, children, adolescents, dental treatment, general anaesthesia.

DOI: $10.2478 / \mathrm{pjph}-2014-0006$

\section{INTRODUCTION}

Epilepsy is a neurological disorder, with varying morphology and aetiology, characterized by recurring seizures. It is estimated that $1-3 \%$ of the population suffer from epilepsy [1]. Neurological deficiencies most frequently correlated with this disease are physical disability and mental development retardation. Psychosocial and educational problems are also present. Intellectual handicap occurs in $5-83 \%$ of patients with epilepsy, physical disability - in $23-54 \%$, a significant decrease in muscle strength - in 52\% [2]; permanent mental disorders related to brain injury (torpor, personality disorders) also occur [3]. This leads to, among other things, more frequent and intense dental caries, as well as periodontal diseases, with the resulting special dental care needs.

\section{AIM \\ The aim of the study was to evaluate the structure of treat- ment procedures in conservative dentistry and dental surgery}

performed under general anaesthesia in children and adolescents with epilepsy.

\section{MATERIAL AND METHODS}

The analysis covered histories of 109 patients with epilepsy, aged 3-18 years, who received dental treatment under general anaesthesia in the years 2010-2012 at the Specialist Dental Surgery at the Provincial Hospital No. 2 in Rzeszów, Poland. The studied group consisted of 52 girls (48\%) and 57 boys (52\%). Dental treatment was provided in an operating room with anaesthesia equipment, basic monitoring devices and full resuscitation equipment, as well as the necessary dental equipment, tools and materials.

The patients were divided into three age groups, according to the dentition type: patients with deciduous dentition 3-5 years of age -10 patients ( $9 \%$ of the study group); with mixed dentition $-6-12$ years -36 patients ( $35 \%$ of the study group), and with permanent dentition - 13-18 years - 63 patients (56\% of the study group).

\footnotetext{
${ }^{1}$ Specialist Dental Surgery, Provincial Hospital No. 2 in Rzeszów, Poland

${ }^{2}$ Chair and Department of Paedodontics, Medical University of Lublin, Poland

${ }^{3}$ Postgraduate trainee dentist; The Infant Jesus Teaching Hospital, Medical University of Warsaw, Poland
} 


\section{RESULTS}

In all the patients treated under general anaesthesia, dental plaque was removed with hand and ultrasonic tools, teeth surfaces were polished, and after treatment procedures, teeth were varnished with fluoride preparations. Therapeutic procedures included: treatment of deep caries in deciduous teeth - 94 carious cavities; deciduous teeth extraction -144 teeth; treatment of moderate caries in permanent teeth -282 carious cavities; treatment of deep caries in permanent teeth - 450 carious cavities; endodontic treatment of permanent teeth -2 teeth; 1 crown reconstruction after a permanent tooth injury, permanent teeth extractions - 109 teeth.

In the youngest age group 55 deciduous teeth were treated for caries: the teeth involved were most frequently first molars, least frequently - central incisors. In the age group 6-12 years, 39 deciduous teeth were treated: most frequently these were first molars, least frequently - lateral incisors (Table 1). In one child with full deciduous dentition, the average number of treated teeth was 5.5, while in the group with mixed dentition the number of treated deciduous teeth reached almost 1.1 .

TABLE 1. The number of treated deciduous teeth in different age groups.

\begin{tabular}{lccc}
\hline \hline & \multicolumn{3}{c}{ Number of treated deciduous teeth } \\
\hline Tooth & $\begin{array}{c}\text { Age } \\
\text { 3-5 years }\end{array}$ & $\begin{array}{c}\text { Age } \\
\text { 6-12 years }\end{array}$ & $\begin{array}{c}\text { Age } \\
\text { 13-18 years }\end{array}$ \\
\hline Central incisor & 6 & 2 & 0 \\
\hline Lateral incisor & 8 & 1 & 0 \\
\hline Canine & 15 & 11 & 0 \\
\hline First molar & 18 & 17 & 0 \\
\hline Second molar & 8 & 8 & 0 \\
\hline Total & 55 & 39 & 0 \\
\hline
\end{tabular}

TABLE 2. The number of extracted deciduous teeth in different age groups.

\begin{tabular}{lccc}
\hline \hline \multicolumn{4}{c}{ Number of extracted deciduous teeth } \\
\hline Tooth & $\begin{array}{c}\text { Age } \\
\text { 3-5 years }\end{array}$ & $\begin{array}{c}\text { Age } \\
6-12 \text { years }\end{array}$ & $\begin{array}{c}\text { Age } \\
13-18 \text { years }\end{array}$ \\
\hline Central incisor & $2(5.1 \%)$ & $4(4.1 \%)$ & 0 \\
\hline Lateral incisor & $3(7.7 \%)$ & $8(8.2 \%)$ & 0 \\
\hline Canine & $3(7.7 \%)$ & $14(14.3 \%)$ & 3 \\
\hline First molar & $18(46.2 \%)$ & $37(37.7 \%)$ & 0 \\
\hline Second molar & $13(33.3 \%)$ & $35(35.7 \%)$ & 4 \\
\hline Total & $39(100 \%)$ & $98(100 \%)$ & 7 \\
\hline
\end{tabular}

Table 2 shows the number of extracted deciduous teeth in different age groups. In the group of 3-5-year olds (10 patients), 39 teeth were extracted: most frequently first molars $(46.2 \%$ of all the extracted deciduous teeth in this age group), and least frequently central incisors (5.1\% all the extracted deciduous teeth in this age group). In this age group, the average number of extracted deciduous teeth per child was 3.9.

In the group of 6-12-year olds, 98 teeth were extracted: most frequently first deciduous molars $(37.7 \%$ of all the extracted teeth in this age group), and least frequently central incisors. In the group of children with mixed dentition, the average number of extracted deciduous teeth per child was 2.7 .

In the group of 13-18-year olds, 7 retained deciduous teeth were extracted.

On the basis of medical records, the number of treated carious cavities in deciduous and permanent teeth, looking at the teeth group with lesions, the treated tooth surface, and the stage of caries progression were determined. The results were totalized and assigned to the age groups. The detailed results, in the form of 10 tables, are available from the authors.

Figures 1 and 2 show the number of permanent teeth surfaces with caries in age groups 6-12 years and 13-18 years, regardless of the teeth group. In the former group 178 teeth surfaces required treatment, in the latter group - 554. In the group of 6-12-year olds, most carious cavities in permanent teeth were localized on the occlusal surfaces (42.7\%), least on distal-buccal surfaces (3.4\%). In the group of 13-18-year olds, most lesions were found on occlusal surfaces $(33.0 \%)$, least - on distal-buccal and mesial-buccal surfaces $(2.4 \%$ per each surface)

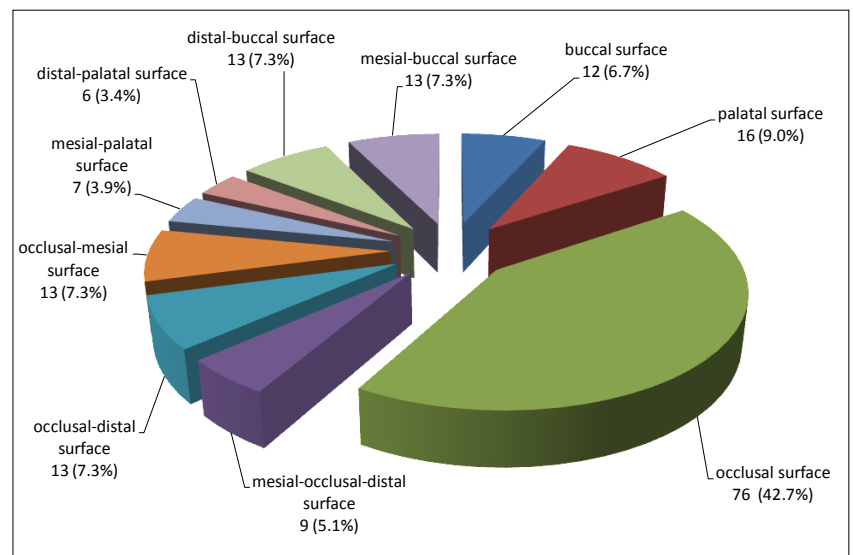

FIGURE 1. The number of permanent teeth surfaces with caries in the age group 6-12 years.

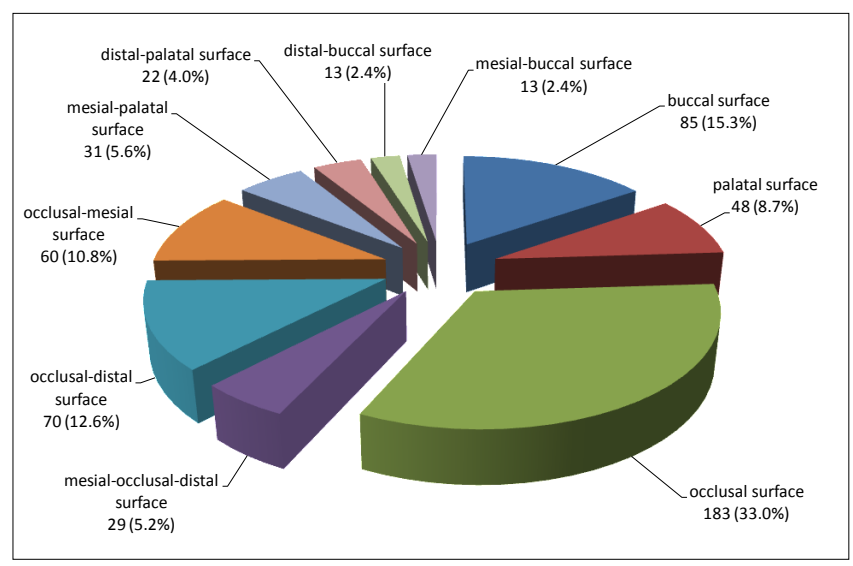

FIGURE 2. The number of permanent teeth surfaces with caries in the age group 13-18 years. 
Table 3 shows the number of extracted permanent teeth. In the group of 6-12-year olds, 14 teeth were extracted, in the group of 13-18-year olds - 95 teeth. In both age groups first permanent molars were extracted most frequently, while in the younger group no first premolar was removed, in the older group least canines were removed. The average number of extracted teeth per patient is: in 6-12 age group almost 0.4 , and in 13-18 age group -1.5 .

TABLE 3. The number of extracted permanent teeth in age groups 6-12 years and 13-18 years.

\begin{tabular}{|c|c|c|}
\hline \multicolumn{3}{|c|}{ Number of extracted permanent teeth } \\
\hline Tooth & Age 6-12 years & Age $13-18$ years \\
\hline Central incisor & $2(14.3 \%)$ & $11(11.6 \%)$ \\
\hline Lateral incisor & $2(14.3 \%)$ & $9(9.5 \%)$ \\
\hline Canine & $2(14.3 \%)$ & $3(3.2 \%)$ \\
\hline First premolar & 0 & $15(15.8 \%)$ \\
\hline Second premolar & $1(7.1 \%)$ & $5(5.2 \%)$ \\
\hline First molar & $7(50 \%)$ & $40(42.1 \%)$ \\
\hline Second molar & 0 & $12(12.6 \%)$ \\
\hline Third molar & 0 & 0 \\
\hline Total & $14(100 \%)$ & $95(100 \%)$ \\
\hline
\end{tabular}

\section{DISCUSSION}

Patients with epilepsy constitute a group characterized by a high risk of pathological abnormalities in the oral cavity: a greater intensity of caries and periodontal diseases than in healthy individuals. This is the consequence of combined effect of numerous factors, which include: difficulties in performing hygienic care in the oral cavity due to physical and mental disability, malocclusions occurring more frequently than in the healthy population, abnormal pattern of breathing, intake of drugs increasing secretion, changing saliva properties, and causing drug-induced gingival hypertrophy $[3,4]$. In patients with epilepsy there is also an increased risk of injuries to oral cavity soft tissues and teeth $[5,6]$.

Our study shows that in children and adolescents with epilepsy who refuse to cooperate with the dentist, dental caries effects in the form of necessary teeth extraction concerned, at average, 9.4 deciduous teeth in one child with full deciduous dentition. The fact that in children with full deciduous and mixed dentition molar teeth were the most frequently removed deciduous teeth is also alarming. Premature extractions that considerably precede the natural process of those teeth exfoliation lead to malocclusions and mastication insufficiency - abnormal comminuting of food and digestive disorders.

In the study group, the need of permanent teeth treatment increased with age. This was expressed in the number of tooth surfaces with caries; the occlusal surfaces were most frequently affected. The anatomy of chewing surfaces favours the development and rapid progress of caries, and untreated or negligently treated carious leads to pulprelated complications. This phenomenon was confirmed in our study by the highest percentage of first molars extracted due to caries complications.
Dental treatment under general anaesthesia enables the dentist to perform procedures with highest precision, which is an undoubted advantage of this kind of treatment [7]. In the case of patients with epilepsy, the decision to undertake such a treatment depends on the mental development level and possible behavioural and affective disorders. The lack of cooperation with the patient and a great number of teeth with caries and its complications, and not epileptic seizures, are usually the reasons to treat the patients under general anaesthesia [6]. This was also the case in patients in our study. A disadvantage of the oral cavity treatment under general anaesthesia is that it requires from the dentist a more radical therapy to solve all the problems at the same time, since it is impossible to continue treatment on subsequent visits, as in the case of cooperative patients $[3,8]$. Hence, among other things, a high number of necessary teeth extractions in children and adolescents with epilepsy also in our study.

High therapeutic needs found in our study confirm prophylactic and therapeutic neglect in dental care of children and adolescents with epilepsy. Daily observation indicates that dental treatment is not an integral part of medical care of disabled children or those with chronic systemic diseases. As a result, patients from those groups see the dentist too late, and in many cases, the reason for the first visit is dental pain - a symptom of dental caries complications [9].

Such patients should receive permanent, specialist dental care including professional prophylaxis of caries, and of the diseases of periodontium and oral cavity mucosa, and education [1]. Parents/guardians should be informed on the necessity of performing systematic prophylactic procedures at home, and - in the first place - of regular control visits to the dentist $[10,11]$, but also on the possibility of periodic dental treatment under general anaesthesia in the case of an uncooperative child [8]. Opinions and attitudes of a majority of dentists who reject this treatment are related to a lack of training and experience in performing such procedures [7].

General anaesthesia in clinical dentistry, and especially in conservative treatment, is in Poland subject to many controversies both among doctors and among their potential patients. One can observe a relatively high percentage of children and adolescents for whom, for a variety of health reasons, such a form of dental treatment is advisable, or even necessary. An increasing number of people with poor health potential in the contemporary world results in the necessity to provide services not only in the area of social welfare and education, but also medical and dental care $[8,12]$.

\section{CONCLUSIONS}

1. In patients with epilepsy treated under general anaesthesia, extensive therapeutic needs were found. Such needs result from neglect of dental prophylaxis and treatment in patient's care.

2. The average number of extractions in children with full deciduous dentition was 3.9 teeth, with mixed dentition -2.7 teeth, and the greatest number of deciduous teeth extractions concerned first and second molars.

3. Carious cavities in the occlusal surfaces of permanent teeth, due to deep caries, were the most frequently treated lesions. 
4. Conservative and surgical treatment, combined with prophylactic procedures, performed under general anaesthesia is one of the necessary elements of a complex dental care in children and adolescents who refuse to cooperate with the dentist.

\section{REFERENCES}

1. Shneker BF, Fountain MB. Epilepsy. Dis Mon. 2003;49(7):426-78.

2. Mielnik-Błaszczak M, Skawińska A, Janus M, et al. Ocena stanu higieny jamy ustnej w grupie lubelskich dzieci chorych na padaczkę. Dent Med Probl. 2009;46(2):234-8.

3. Skawińska A, Mielnik-Błaszczak M. Analiza stanu higieny jamy ustnej i periodontologicznych potrzeb leczniczych u dzieci i młodzieży chorych na padaczkę oraz padaczkę ze współwystępującą niepełnosprawnością umysłową. Stand Med Pediatr. 2011;8(3):488-92.

4. Limanowska-Shaw H, Paszyńska E, Deręgowska-Nosewicz P, et al. Ocena stanu dziąseł oraz nawyków higienicznych u sportowców olimpiad specjalnych. Czas Stomatol. 2003;56(6):415-20.

5. Szyperska AM, Janas A, Cyl M, Grzesiak-Janas G. Pacjenci z epilepsją w gabinecie stomatologicznym. Porad Stomatol. 2010;10(9):308-10.

6. Olszanecka M, Chmielnik J. Postępowanie w gabinecie stomatologicznym z dziećmi dotkniętymi padaczką i ADHD. Twój Przegl Stomatol. 2011;(5):62-4.
7. Bladowski M, Iwanowska-Sosnowska M, Nischk M. Stomatologia zachowawcza w znieczuleniu ogólnym. Tryb ambulatoryjny. Interpretacja i propozycja nowych przepisów dotyczących przeprowadzania zabiegów z zakresu stomatologii klinicznej w znieczuleniu ogólnym. Nowa Stomatol. 2001;1:37-45.

8. Szymańska J, Bogucka-Gordziejko M. Zabiegi stomatologiczne wykonywane w znieczuleniu ogólnym u pacjentów w wieku rozwojowym. Czas Stomatol. 1999;52(9):591-6.

9. Borysewicz-Lewicka M, Gerreth K, Wiśniewska K, Wysocki J. Leczenie stomatologiczne jako część wymaganej opieki medycznej nad dziećmi niepełnosprawnymi - opinia rodziców. Dent Med Probl. 2011;48(1):4553.

10. Postek-Stefańska L, Ziętek P. Stan narządu żucia i problemy związane z leczeniem stomatologicznym dzieci chorujących na padaczkę. Przegląd piśmiennictwa. Mag Stomatol. 2005;15(11):10-3.

11. Brodie MJ, Frencz JA. Management of epilepsy in adolescents and adults. Lancet. 2000;356:323-9.

12. Michałowski A, Mielnik-Błaszczak M, Skawińska A, et al. Zabiegi stomatologiczne w znieczuleniu ogólnym w materiale Katedry i Zakładu Stomatologii Wieku Rozwojowego UM w Lublinie - obserwacja roczna. Mag Stomatol. 2009;19(9):70-2.

\section{Corresponding author}

Jolanta Szymańska

Chair and Department of Paedodontics,

Medical University of Lublin

7 Karmelicka Str., 20-081 Lublin, Poland

E-mail: szymanska.lublin@gmail.com 